\title{
MEMBANGUN KARAKTER KONSERVASI MELALUI ORIGAMI BAGI PEMBELAJAR BAHASA JEPANG
}

\section{Building Character Conservation through Origami for Japanese Language Learners}

\section{Lispridona Diner}

Universitas Negeri Semarang,

Semarang, Central Java,

Indonesia

email: lisjoost@yahoo.com

\begin{abstract}
Abstrak
Pendidikan karakter memiliki peranan penting dalam perkembangan individu. Setiap individu yang memiliki karakter baik dimulai sejak dini. Di Indonesia Pendidikan karakter beberapa tahun terakhir menjadi bagian dari Pendidikan formal. Dimulai dengan adanya PAUD berbasis karakter, dilanjutkan dengan SD hingga SMA/MK/MAN yang menggunakan kurikulum yang dikenal dengan sebutan kurikulum 2013 (kurtilas atau K I3). Pada perguruan tinggi seperti Universitas Negeri Semarang (UNNES) sejak tanggal 12 Maret 2010 UNNES mendeklarasikan diri menjadi Universitas Konservasi. Sebagai Universitas Konservasi, Sejak saat itu UNNES memiliki visi "menjadi universitas konservasi bertaraf internasional, yang sehat, unggul, dan sejahtera pada tahun 2020". Untuk mendukung program tersebut, maka dilakukan Pelaksanaan kepada masyarakat yaitu mewujudkan Pendidikan karakter melalui origami. Metode pelaksanaan pada program Pelaksanaan ini adalah pengajaran dan evaluasi. Pelaksana sebagai observer yang mengamati langsung proses kegiatan Pelaksanaan kepada masyarakat dari awal hingga akhir. Pada pelaksanaan peserta yang hadir 32 orang. Berdasarkan kegiatan yang telah dilaksanakan dapat disimpulkan bahwa melalui origami dapat mewujudkan karakter konservasi UNNES yaitu humanis, kreatif dan jujur sebesar $100 \%$, Inspiratif, peduli, sportif dan adil sebesar $80 \%$. Sedangkan inovatif sebesar $70 \%$.
\end{abstract}

Kata Kunci:

Karakter

Konservasi

Origami

Keywords:

Character

Conservation

Origami

\section{Accepted}

September 2018

Published

December 2018

\begin{abstract}
Character education has an important role in individual development. Every individual who has good character starts early. In Indonesia character education in recent years has become part of formal education. It starts with character-based PAUD, followed by SD to SMAIMKIMAN which uses a curriculum known as the 2013 curriculum (kurtilas or KI3). At universities such as Semarang State University (UNNES) since March I2, 2010 Unnes declared itself to be a Conservation University. As a Conservation University, since then UNNES has a vision of "becoming an international-standard conservation university that is healthy, superior and prosperous in 2020". To support the program, community service is carried out by realizing character education through origami. The method of implementation in this service program is teaching and evaluation. The servant is an observer who observes the process of directing the activities directly to the community from the beginning to the end. On the implementation of the participants were 32 people. Based on the activities that have been carried out it can be concluded that through origami can realize the character of conservation of UNNES which is humanistic, creative and honest by $100 \%$, inspirational, caring, sporty and fair at $80 \%$. While innovative is $70 \%$.
\end{abstract}

\section{PENDAHULUAN}

Pendidikan karakter memiliki peranan penting dalam perkembangan individu. Setiap individu yang memiliki karakter baik dimulai sejak dini. Di Indonesia Pendidikan karakter beberapa tahun terakhir menjadi bagian dari Pendidikan formal. Dimulai dengan adanya PAUD berbasis karakter, dilanjutkan dengan SD hingga SMA/MK/MAN yang menggunakan kurikulum yang dikenal dengan sebutan kurikulum 2013 (kurtilas atau KI3) (Samrin, 2016).
Pendidikan karakter menjadi bagian penilaian dalam pembelajaran di kelas pada SD hingga pendidikan menengah. Hal ini sejalan dengan program pemerintah tentang revolusi mental. Pendidikan karakter menjawab tantangan masa kini yang sedang dihadapi oleh individu atau kelompok ditengah maraknya era globalisasi dan perkembangan teknologi serta arus masuknya budaya asing dan produk asing dengan bebas ke Indonesia (Hartoyo, 20I5). 
Pada perguruan tinggi seperti Universitas Negeri Semarang (UNNES) sejak tanggal I 2 Maret 2010 Unnes mendeklarasikan diri menjadi Universitas Konservasi. Sebagai Universitas Konservasi, UNNES bertekad untuk menerapkan prinsip-prinsip perlindungan, pengawetan, dan pemanfaatan secara lestari terhadap sumber daya alam dan seni budaya, serta berwawasan ramah lingkungan dalam pelaksanaan Tri Dharma Perguruan Tinggi. Pada tahun 20II, berdasarkan Peraturan Menteri Pendidikan Nasional Republik Indonesia Nomor 8 tahun 2011 tentang Statuta Universitas Negeri Semarang, visi UNNES sebagai Universitas Konservasi kian Tegas. Sejak saat itu UNNES memiliki visi "Menjadi universitas konservasi bertaraf internasional, yang sehat, unggul, dan sejahtera pada tahun 2020”. Hal ini kian meneguhkan posisi penting Badan Pengembang Universitas Konservasi sebagai badan yang berperan penting untuk mewujudkan visi Unnes. Sejak saat itu, Tim Konservasi pada tahun 201 I menjadi Badan Pengembangan Universitas Konservasi berdasarkan SK Rektor Unnes Nomor 35/P/20II. Badan Pengembangan Konservasi UNNES merupakan salah satu Badan yang ada di UNNES, dan mempunyai tugas untuk mengembangkan nilai-nilai konservasi di lingkungan UNNES dan sekitarnya.

Membangun terwujudnya konservasi di UNNES, maka setiap kurikulum di setiap program studi memiliki mata kuliah konservasi dan setiap materi pada mata kuliah pun terdapat karakter konservasi. Seperti pada prodi pendidikan bahasa Jepang yaitu mata kuliah nihonjijo. Sebelum melaksanakan perkuliahan pengajar wajib membuat RPS (Rencana Pengajaran Semester). Dalam RPS wajib mecantumkan secara rinci dan jelas karakter konsevasi yang akan jadi bagian penilaian pengajar kepada mahasiswa. Diantaranya mata kuliah Nihonjijo. Melalui mata kuliah ini mahasiswa belajar budaya Jepang, cara berpikir orang Jepang, keadaan Jepang dan kebiasaan orang Jepang. Materi yang disampaikan diantaranya yaitu origami. Origami adalah seni melipat kertas. Namun, materi yang disampaikan pada perkuliahan nihonjijo, terbatas dengan waktu. Dikarenakan penyampaian materi ini jika dikembangkan dapat berupa teori dan praktek. Sedangkan selama ini dilakukan oleh pengajar langsung pada praktek. Diharapkan belajar budaya Jepang tanpa mengabaikan nilai karakter konservasi, maka perlu sebuah kegiatan yang dapat menunjang dalam membangun karakter konservasi.

Origami (折り紙, dari ori yang berarti “lipat”, dan kami yang berarti "kertas" merupakan seni tradisional melipat kertas yang berkembang menjadi suatu bentuk kesenian yang modern. Origami adalah sebuah seni lipat yang berasal dari Jepang. Bahan yang digunakan adalah kertas atau kain yang biasanya berbentuk persegi. Secara umum untuk membuat origami kita bisa menggunakan kertas biasa namun kebanyakan origami di Jepang menggunakan kertas khusus untuk origami. Perbedaan antara kertas biasa dan kertas origami hanyalah dari segi desain dan warna saja. Warna kertas yang digunakan untuk origami sangat beragam sehingga membuat origami menjadi semakin indah (Karmachela, 2008).

Origami merupakan satu kesenian melipat kertas yang dipercayai bermula semenjak kertas mula diperkenalkan pada abad pertama di Tiongkok pada tahun 105 oleh seorang Tiongkok yang bernama Ts'ai Lun. Pembuatan kertas dari potongan kecil tumbuhan dan kain berkualitas rendah meningkatkan produksi kertas. Contoh-contoh awal origami yang berasal daripada Republik Rakyat Tiongkok adalah tongkang Tiongkok dan kotak (Isao, 1965).

Pada abad ke-6, cara pembuatan kertas kemudian dibawa ke Spanyol oleh orang-orang Arab. Tahun 610 di pemerintahan kaisar wanita Suiko (zaman Asuka), seorang biksu Buddha bernama Donchō (Dokyo) yang berasal dari Goguryeo (semenanjung Korea) datang ke Jepang mengenalkan cara pembuatan kertas dan tinta. Kemudian berkembang di Jepang yakni pada zaman Muromachi (1333-1568) dan kemudian pada zaman Edo (1603-1868). Bentuk atau model yang dikenal saat itu 
terbatas pada model tradisional seperti bangau di Jepang dan pajarita di Spanyol. Akira Yoshizawa (1911-2005) membuat inovasi dengan menciptakan model baru, kemudian membawa perubahan besar dalam perkembangan origami. Beliau menciptakan sebuah sistem penggambaran sistemastis (diagram) untuk menunjukkan langkah-langkah pelipatan suatu model yang dapat disebarluaskan dan dipahami oleh banyak pihak. Sistem ini adalah dasar dari Sistem YoshizawaRandlett yang sekarang lazim digunakan untuk instruksi lipat model origami.

Origami mempunyai dua jenis, yang sering diebut dengan istilah model, yaitu model tradisional dan model orisinal atau dapat disebut juga dengan model modern. Model tradisional merupakan model yang umum/populer dan biasanya tidak dikenal lagi siapa yang mendesain pertama kalinya. Meski jumlahnya banyak sekali, biasanya model tradisional ini merupakan bentuk-bentuk lama. Sementara model orisinal merupakan karya-karya kontemporer buatan masing-masing para pelipat kertas dan dicantumkan namanya sebagai hak cipta mereka.

Bahan yang paling dibutuhkan untuk membuat origami adalah kertas. Awalnya ketika membuat satu model origami hanya dari selembar kertas tanpa tambahan bahan atau alat apapun. Kertas yang dibutuhkan adalah kertas yang tipis namun kuat yang mempunyai karakteristik mudah dan enak dilipat. Sebaiknya bukan kertas yang tebal (semacam karton tebal), atau terlalu lentur (seperti kertas tisu) karena itu akan menyulitkan. Biasanya kertas yang digunakan untuk origami berwarnawarni. Warna umumnya hanya ada pada satu sisi sementara sisi lainnya putih polos. Akan tetapi, pada perkembangannya menjadi bermacam-macam, seperti berwarna pada kedua sisi atau bercorak atau berpola sehingga semakin menarik.

Manfaat Origami bagi perkembangan anak kecil dan dewasa. Origami biasanya hanya diajarkan di TK padahal manfaatnya juga masih bisa didapat oleh anak SD dan juga orang dewasa. Kegiatan Origami dengan kedua tangan membuat otak kanan dan otak kiri berinteraksi. $\mathrm{Hal}$ ini dapat meningkatkan kecerdasan verbal dan nonverbal. Untuk anak-anak yang lebih dewasa, kegiatan origami dapat meningkatkan imajinasi dan figurative thinking (Kemampuan mewujudkan impian jadi kenyataan) (Mutiah, 20l0).

UNNES tahun 2010 telah mendeklarasikan diri sebagai universitas konservasi. Sejalan dengan itu, pada tahun 2016, seluruh warga UNNES telah menyepakati visi UNNES, yaitu menjadi universitas berwawasan konservasi dan bereputasi internasional. Visi ini sangat mulia, terutama ruh utamanya, yaitu menjadikan konservasi sebagai landasan berpikir, bersikap, dan bertindak bagi seluruh warga UNNES. Konservasi ini ingin diwujudkan dalam seluruh aktivitas UNNES baik dalam bidang tridharma perguruan tinggi yang dilakukan oleh dosen dan mahasiswa, maupun dalam pergaulan kehidupan kampus yang mempertemukan kehadiran dosen, tenaga kependidikan, dan mahasiswa dalam suatu relasi yang harmonis. Salah satu pilar konservasi yang dijadikan pijakan bagi warga kampus dalam berpikir, bersikap, dan bertindak adalah pilar nilai dan karakter. Nilai dan karakter konservasi telah dikembangkan oleh masing-masing fakultas dan menjadi miliki bersama seluruh warga UNNES. Nilai dan karakter itu meliputi nilai inspiratif, nilai humanis, nilai peduli, nilai inovatif, nilai kreatif, nilai sportif, nilai jujur, dan nilai adil (Wibowo, 2017)

\section{METODOLOGI}

Metode pelaksanaan yang dilakukan adalah pelatihan dan evaluasi. Pelaksana memberikan pelatihan dan mengamati langsung proses kegiatan pengabidan kepada masyarakat dari awal hingga akhir. Pelatihan origami dilakukan tiga kali pertemuan. Pada pertemuan pertama adalah penyampaian tentang origami, apa itu origami, bagaimana dan teknik apa saja yang digunakan dalam membuat origami, serta manfaat origami. Pertemuan kedua adalah praktek membuat origami. Pertemuan 
ketiga, evaluasi apa saja yang perlu diperbaiki dalam membuat origami. Pengamatan yang dilakukan oleh pelaksana adalah mengamati pembuatan origami dan karakter konsevasi apa yang muncul dalam proses pembuatan origami.

\section{HASIL DAN PEMBAHASAN}

Pertemuan pertama materi yang disampaikan adalah tentang origami, apa itu origami, bagaimana dan teknik apa saja yang digunakan dalam membuat origami, dan manfaat origami. Pelaksanaan pada hari pertama membutuhkan waktu $2 \times 50$ menit. Ix50 menit awal, peserta berdiskusi tentang origami yang mereka kenal selama ini. Pelaksana lalu membandingkannya dengan origami yang dilakukan di Indonesia. Lalu menyampaikan hasil diskusi tersebut di depan kelas.

Pelaksanaan IX50 menit selanjutnya adalah menyampaikan materi, peserta menyimak isi materi dan memahami tentang origami. Lalu peserta diberi kesempatan untuk menyampaikan hasil pemahaman setelah menerima materi. Peserta diminta menyiapkan ide bentuk origami yang akan dipraktekan pada pertemuan kedua. Peserta hadir seluruhnya berjumlah 32 peserta. Karakter konservasi yang sering nampak pada pertemuan ini adalah inspiratif $60 \%$ dan jujur $70 \%$.

Penjelasan tentang kedua karakter konservasi tersebut terdapat pada Tabel I.

Tabel I. Karakter konservasi yang nampak pada pertemuan I

\begin{tabular}{|c|c|c|}
\hline $\begin{array}{c}\text { Karakter } \\
\text { Konservasi }\end{array}$ & $\begin{array}{c}\text { Persentasi } \\
\text { (\%) }\end{array}$ & Keterangan \\
\hline Inspiratif & 60 & $\begin{array}{l}\text { Ketika menyampaikan materi ini, } \\
\text { I7 peserta pernah mendengar dan } \\
\text { tahu tentang origami. Dari } 17 \\
\text { Peserta } 6 \text { diantaranya pernah } \\
\text { membuat origami dan } 2 \text { dari } 6 \\
\text { peserta pernah membuat origami } \\
\text { karakter Jepang seperti tsuru. Hal } \\
\text { di atas dapat menjadi ispirasi bagi } \\
\text { peserta lainnya. }\end{array}$ \\
\hline Humanis & 30 & $\begin{array}{l}\text { Ketika diminta memberikan } \\
\text { pendapat tentang definisi origami, } 6 \\
\text { peserta yang memiliki pendapat } \\
\text { yang berberda dengan teman }\end{array}$ \\
\hline
\end{tabular}

\begin{tabular}{|c|c|c|}
\hline & & $\begin{array}{l}\text { lainnya. Namun mereka saling } \\
\text { menghargai satu dengan lainnya. }\end{array}$ \\
\hline Peduli & 10 & $\begin{array}{l}2 \text { peserta peduli terhadap sekitar, } \\
\text { ketika tim pelaksana menyiapkan } \\
\text { dan membagikan materi. Peserta } \\
\text { tersebut datang kepada tim } \\
\text { pelaksana beinisiatif memberikan } \\
\text { bantuan untuk membagikan } \\
\text { materi. }\end{array}$ \\
\hline Inovatif & - & - \\
\hline Kreatif & - & - \\
\hline Sportif & - & - \\
\hline Jujur & 70 & $\begin{array}{l}28 \text { mengungkapkan dengan jujur } \\
\text { tentang origami Baik itu pernah } \\
\text { membuat origami maupun belum } \\
\text { pernah membuat origami serta } \\
\text { menyampaikan definisi origami } \\
\text { menurut pemahaman mereka } \\
\text { selama ini. }\end{array}$ \\
\hline
\end{tabular}

Pertemuan kedua, praktek membuat origami dalam waktu $2 \times 50$ menit. Peserta dibagi kelompok, setiap kelompok terdiri dari 5-6 peserta. Setiap kelompok menunjuk dua orang sebagai presenter yang akan menunjukkan cara membuat origami sesuai dengan model atau bentuk origami yang telah disepakati oleh kelompok, anggota kelompok lain bertugas mendampingi peserta kelompok lain yang sedang membuat origami. Karakter konservasi yang nampak di pertemuan 2 dapat dilihat pada Tabel 2.

Tabel 2. Karakter konservasi yang nampak pada pertemuan 2

\begin{tabular}{cccll}
\hline $\begin{array}{c}\text { Karakter } \\
\text { Konservasi }\end{array}$ & $\begin{array}{c}\text { Persentasi } \\
(\%)\end{array}$ & \multicolumn{2}{l}{ Keterangan } \\
\hline Inspiratif & 80 & Ketika & membuat origami, 5
\end{tabular}
kelompok yang tampil tidak ada origami yang sama. Kelompok I adalah origami kelinci, kelompok 2 : origami ikan, kelompok 3: origami, kelompok 4: origami kucing, kelompok 5: origami yukata (baju tradisional Jepang). Cara membuat dan Teknik membuat origami dan cara penyampaian dengan santun, serta bentuk origami tidak memiliki kesamaan sehingga dapat menjadi inspirasi kelompok lain.

Humanis $100 \quad$ Ketika salah satu kelompok
menampilkan cara membuat
origami, kelompok lain menyimak
dan mengikuti proses tersebut
dengan baik. Jika ada yang bertanya
dan terlambat. Penampil dengan
sabar mendampingi dan
menjelaskan. Sikap humanis yang
nampak yaitu saling menghargai




\begin{tabular}{|c|c|c|}
\hline & & $\begin{array}{l}\text { dan toleransi satu kelompok } \\
\text { dengan kelompok lain. }\end{array}$ \\
\hline Peduli & 80 & $\begin{array}{l}\text { Anggota kelompok yang tidak } \\
\text { presentasi mendampingi anggota } \\
\text { kelompok yang sedang membuat } \\
\text { origami. Kepedulian lain lain yang } \\
\text { ditunjukkan adalah ketika } \\
\text { beberapa peserta kehabisan kertas } \\
\text { origami, peserta lain bersedia } \\
\text { membagikan kertas origami. }\end{array}$ \\
\hline Inovatif & 70 & $\begin{array}{l}\text { Pada kegiatan ini setiap anggota } \\
\text { kelompok yang tidak presentasi di } \\
\text { depan mendampingi anggota } \\
\text { kelompok lain dengan cara } \\
\text { berkeliling. Selain itu, setiap } \\
\text { anggota kelompok membuat } \\
\text { origami yang berbeda bersedia dan } \\
\text { antusias. Cara pikir yang inovatif ini } \\
\text { yaitu tidak takut terhadap } \\
\text { perubahan. }\end{array}$ \\
\hline Kreatif & 100 & $\begin{array}{l}\text { Setiap kelompok menampilkan } \\
\text { cara membuat origami yang } \\
\text { berbeda dan menggunakan kertas } \\
\text { sesuai origami yang dibuat seperti } \\
\text { membuat yukata menggunakan } \\
\text { kertas yang berbunga. Hal tersebut } \\
\text { menunjukkan karakter konservasi } \\
\text { yaitu kreatif. }\end{array}$ \\
\hline Sportif & 80 & $\begin{array}{l}\text { Pada saat salah satu kelompok } \\
\text { keliru dalam menjelaskan cara } \\
\text { membuat origami ikan. Anggota } \\
\text { kelompok lain kritis memberikan } \\
\text { pendapat dan memperbaiki. } \\
\text { Kelompok yang menjelaskan } \\
\text { dengan senang hati memerima dan } \\
\text { memperbaiki origami tersebut. } \\
\text { Karakter konservasi sportif juga } \\
\text { nampak pada saat itu. }\end{array}$ \\
\hline Jujur & 100 & $\begin{array}{l}\text { Semua kelompok jujur } \\
\text { menyampaikan cara membuat } \\
\text { origami. Dan mengakui kekeliruan } \\
\text { ketika mengalami kesalahan dalam } \\
\text { membuat origami }\end{array}$ \\
\hline Adil & 80 & $\begin{array}{l}\text { Setiap kelompok dengan adil } \\
\text { membagi perhatian dan } \\
\text { menjelaskan cara membuat origami } \\
\text { kepada kelompok lain. Hal ini } \\
\text { ditunjukkan dengan anggota } \\
\text { kelompok yang presentasi } \\
\text { mendampingi anggota kelompok } \\
\text { menyebar untuk mendampingi } \\
\text { anggota kelompok yang sedang } \\
\text { membuat origami. }\end{array}$ \\
\hline
\end{tabular}

Dokumentasi proses kegiatan pembuatan origami serta hasil origami yang diperoleh disajikan pada Gambar I sampai 7.

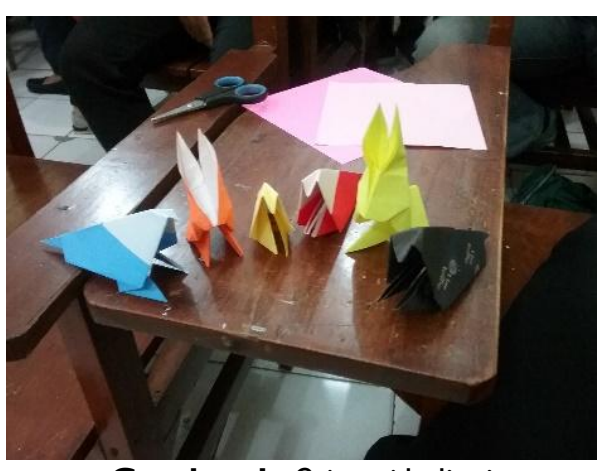

Gambar I. Origami kelinci

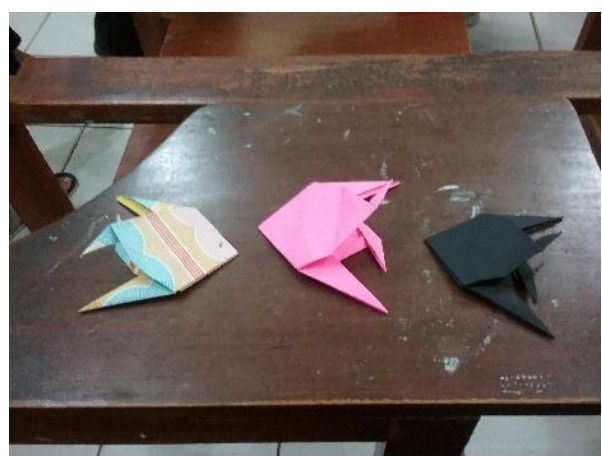

Gambar 2. Origami ikan

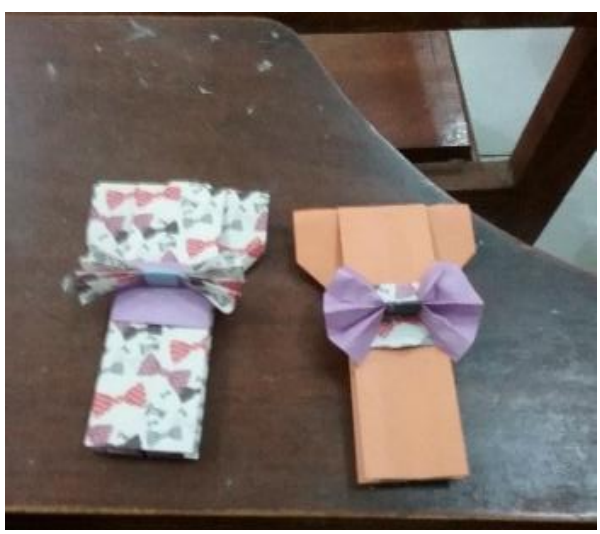

Gambar 3. Origami yukata

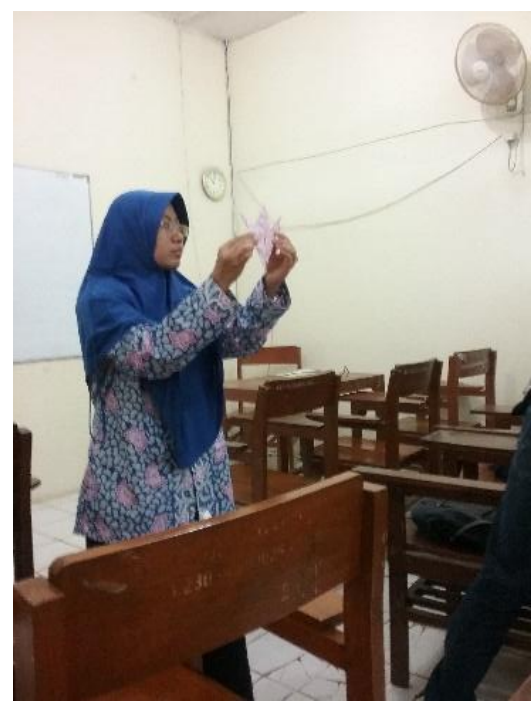

Gambar 4. Presentasi origami 


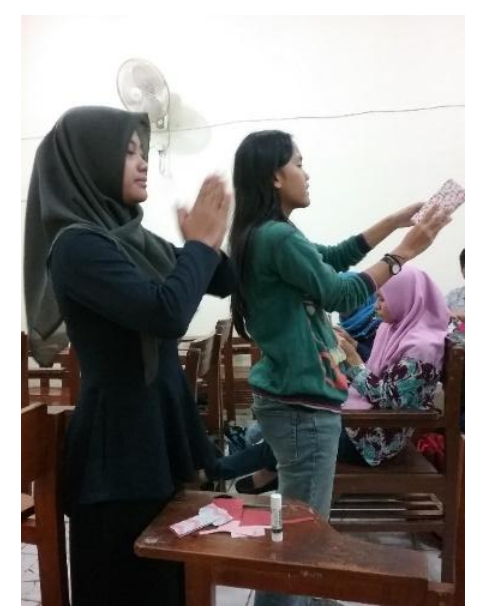

Gambar 5. Kerjasama kelompok

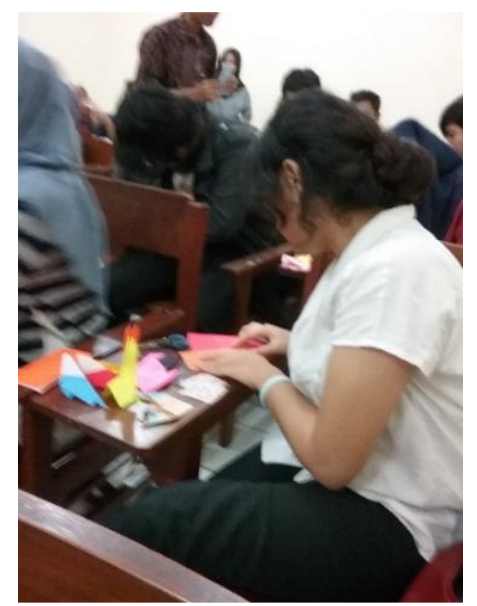

Gambar 6. Pembuatan origami

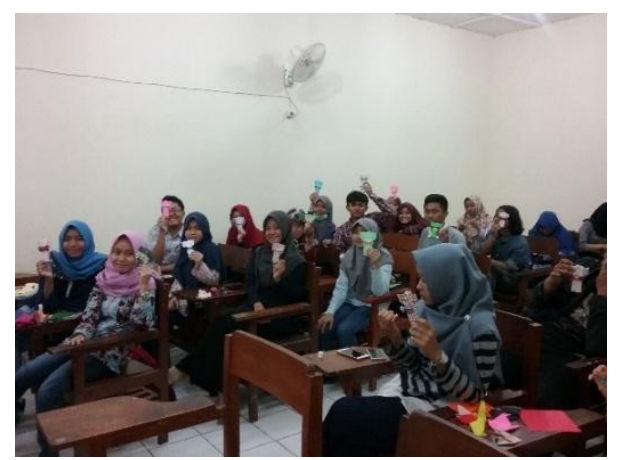

Gambar 7. Peserta menunjukkan hasil origami

Dari gambar kegiatan di atas dapat dilihat beberapa hasil origami yang dibuat oleh peserta, yaitu origami kelinci, ikan, dan yukata. Karakter konservasi yang nampak pada kegiatan tersebut dapat dilihat pada saat kegiatan presentasi origami dan kerjasama kelompok, yaitu inspiratif. Pada saat pembuatan dan menunjukkan hasil origami, karakter konservasi yang nampak adalah kreatif.
Pertemuan 3 yaitu tahap evaluasi. Peserta disebarkan angket, hasil angket yang kami terima peserta memiliki kesan baik terhadap kegiatan ini. Peserta dapat hadir 32 orang setiap pertemuan. Saat kegiatan berlangsung peserta antusias bertanya dan menjawab pertanyaan yang diajukan tim pelaksana.

\section{KESIMPULAN}

Berdasarkan pelaksanaan kegiatan dapat disimpulkan bahwa melalui kegiatan origami dapat dilihat karakter konservasi yang nampak. Karakter konservasi yang nampak pada setiap peserta adalah humanis, kreatif dan jujur yaitu $100 \%$. Artinya semua peserta dalam membuat origami bersikap humanis, kreatif dan jujur. Meskipun dilain pihak, terdapat juga peserta yang belum menunjukkan karakter konservasi seperti inovatif, peduli, inspiratif dan adil. Oleh karena itu perlu sekiranya dalam setiap kegiatan di lingkungan UNNES mendukung konservasi dan bernilai karakter konservasi yang sudah digalakkan selama ini.

\section{REFERENSI}

Hartoyo, A. 2015. Pembinaan Karakter Dalam Pembelajaran Matematika. Math Didactic: Jurnal Pendidikan Matematika. I(I):8-22.

Isao, H. 1965. The World Of Origami. Jepang: Day Nippon Printing.

Karmachela, H. 2008. Origami dan Anak. Surabaya: Insan Cendekia.

Mutiah, D. 2010. Psikologi Bermain Anak Usia Dini. Jakarta: Kencana

Samrin. 2016. Pendidikan Karakter (Sebuah Pendekatan Nilai). Jurnal Al-Ta'dib. 9(I): I 20-I43.

Wibowo, M.E., Suyitno, H., Retnoningsih, A., Handoyo, E., Rahayuningsih, M., Yurniawan, T., Pratama, H., Sunawan, Syaifudin, A., Yulianto, A., \& Surahmat. 2017. Tiga Pilar Konservasi: Penopang Rumah Ilmu Pengembang Peradaban Unggul. Semarang: UNNES Press. 